\title{
BOK Gene
}

National Cancer Institute

\section{Source}

National Cancer Institute. BOK Gene. NCI Thesaurus. Code C126577.

This gene plays a role in the activation of apoptosis. 